\title{
SOLA, María Soler. Campos de la memoria: el testimonio de Primo Levi y Max Aub. Sevilla: Editorial Renacimiento, 2016. 257 p.
}

\author{
Raluca Ciortea \\ Universidad del Oeste de Timisoara, Timisoara / Romênia \\ dra.ralucaciortea@gmail.com
}

El libro Campos de la memoria: el testimonio de Primo Levi y Max $A u b$ trata sobre todos aquellos que han sido reducidos al silencio por la deshumanización, el dolor y la muerte. Se trata de una obligación moral no dejar que la sinvoz de estos se pierda en el olvido. En Campos de la memoria, la autora indaga en el mundo de los campos de concentración y pone en evidencia el ruidoso silencio de aquellos que allí han encontrado su fin. Es un periplo por el laborioso camino de zanjar entre las trincheras de la memoria, colectiva e individual, y redarlos a la vida histórica y social, de expresar el dolor y el trauma que supuso haber estado preso en las garras del infierno concentracionario.

Sola analiza de manera contrastiva la narrativa testimonial de Primo Levi y Max Aub, ambos testigos del doloroso ejercicio de silenciar la palabra y del vivir en el inframundo de los campos de concentración. Para tanto, divide su libro en dos partes fundamentales y, a la vez, complementarias. En la primera parte, la autora se decanta por analizar una serie de conceptos de real importancia para la comprensión de la narrativa memorialística y testimonial de los autores mencionados, y para lo cual se basa en una serie de autores como Tzvetan Todorov, Paul Ricoeur, Joël Candau, Jaume Peri Blanes, Eloísa Nos Aldás, Jorge Semprún, Esther Cohen o Manuel Reyes Mate, entre otros. Allí se tocan nociones tales como memoria, testigo, y testimonio, aunque sea el de desmemoria el que adquiera un mayor protagonismo. Este es, en las 
palabras de la investigadora, «un fantasma capaz de asolar el pasado de los muertos disolviéndolo en su relación con el presente» (SOLA, 2016, p. 10), o tal como decía Primo Levi:

Lo ripeto, non siamo noi, i superstiti, i testimono veri. È questa una nozione scomoda, di cui ho preso conscienza a poco a poco, leggendo le memorie altrui, e rileggendo le mia a distanza di anni. Noi supravvissuti siamo una minoranza anómala oltre che esigua: siamo quelli che, per loro prevaticazione o abilità o fortuna, non hanno toccato il fondo. Chi lo ha fatto, chi ha visto la Gorgone, non è mai ornato per raccontare, o è tornata muto; ma sono loro, i "mussulmani", i sommersi, i terstimoni integrali, coloro la cui deposizione avrebbe avuto significato generale. Loro sono la regola, noi l'eccezione» (LEVI, 2007, p. 64 apud SOLA, 2016, p. 185$){ }^{1}$

En la segunda parte, María Soler Sola se adentra con mucha sutileza investigadora en las entrañas del texto testimonial de Primo Levi y Max Aub. Entre los recursos literarios que los autores han utilizado para plasmar su vivencia y su vivir en los campos cabe mencionar la ironía, lo grotesco, lo macabro y escatológico, la adjetivación, la cosificación, la animalización, las isotopías semánticas del campo de pauperización del cuerpo como hambre, frío, y sed, entre otros. En cuanto a la estructura narrativa, María Soler Sola destaca el interesante juego de voces y la focalización que, en su opinión, sería el «deseo de trascender la propia vivencia personal [...] apuntando hacia una esfera colectiva» (SOLA, 2016, p. 233).

Otro elemento importante que la autora destaca es el hecho de que los autores utilizan el relato fantástico como un medio que les permite comunicar lo incomunicable, y crear la estructura y el ambiente proclive a desatar los lazos del recuerdo.

\footnotetext{
${ }^{1}$ «Lo repito, no somos nosotros, los sobrevivientes, los verdaderos testigos. Ésta es una idea incómoda, de la que he adquirido conciencia poco a poco, leyendo las memorias ajenas, y releyendo las mías después de los años. Los sobrevivientes somos una minoría anómala además de exigua: somos aquellos que por sus prevaricaciones, o su habilidad, o su suerte, no han tocado fondo. Quien lo ha hecho, quien ha visto a la Gorgona, no ha vuelto para contarlo, o ha vuelto mudo; son ellos, los «musulmanes», los hundidos, los verdaderos testigos, aquellos cuya declaración habría podido tener un significado general. Ellos son la regla, nosotros la excepción» (LEVI, 1989, p. 35).
} 
Podríamos decir que el análisis hermenéutico realizado por la investigadora, aunque enfocado en la obra de estos dos grandes maestros de la palabra, y en la manera en la cual estos plasmaron en vocablo esa terrible existencia, lo que en realidad persigue son las maneras en las que expresan el dolor y rinden «homenaje al "hundido" para que su historia no se pierda en el olvido para siempre», porque «reconocer al "caído", rescatarlo del anonimato es devolverlo al mundo y a la memoria de los hombres» (SOLA, 2016, p. 203).

\section{Referencias}

LEVI, Primo. I sommersi e i salvati. Torin: Einaudi, 2007 apud SOLA, María Soler. Campos de la memoria: el testimonio de Primo Levi y Max Aub. Sevilla: Editorial Renacimiento, 2016.

LEVI, Primo. Los hundidos y los salvados. Barcelona: Muchnik Editores, 1989.

SOLA, María Soler. Campos de la memoria: el testimonio de Primo Levi y Max Aub. Sevilla: Editorial Renacimiento, 2016.257 p.

Recebido em: 9 de agosto de 2018. Aprovado em: 2 de novembro de 2018. 